Correspondence

Kozo Asano

asanok@chem.agr.hokudai.ac.jp

\section{Glaciibacter superstes gen. nov., sp. nov., a novel member of the family Microbacteriaceae isolated from a permafrost ice wedge}

\author{
Taiki Katayama, ${ }^{1}$ Tomoko Kato, ${ }^{1}$ Michiko Tanaka, ${ }^{1}$ Thomas A. Douglas, ${ }^{2}$ \\ Anatoli Brouchkov, ${ }^{3}$ Masami Fukuda, ${ }^{4}$ Fusao Tomita ${ }^{5}$ and Kozo Asano ${ }^{1}$
}

${ }^{1}$ Laboratory of Applied Microbiology, Graduate School of Agriculture, Hokkaido University, N9 W9 Kita-ku, Hokkaido 060-8589, Japan

${ }^{2}$ Cold Regions Research and Engineering Laboratory, Fort Wainwright, AK 99703-0170, USA

${ }^{3}$ Tyumen State Oil and Gas University, Tyumen Scientific Center, Siberian Branch of Russian Academy of Sciences, 86 Malygin St., Tyumen 625048, Russia

${ }^{4}$ International Arctic Research Center, University of Alaska, Fairbanks, AK 99775-7340, USA

${ }^{5}$ Hokkaido Study Center, University of the Air, N17 W8 Kita-ku, Hokkaido 060-0817, Japan

\begin{abstract}
Gram-positive, aerobic, non-spore-forming, irregular rod-shaped bacteria, designated strains $\mathrm{AHU} 1791^{\top}$ and $\mathrm{AHU1810}$, were isolated from a permafrost ice wedge in Alaska. Cells were motile by means of a polar flagellum. The strains were psychrophilic, growing at -5 to $25{ }^{\circ} \mathrm{C}$.

Phylogenetic analysis of $16 \mathrm{~S}$ rRNA gene sequences indicated that the ice-wedge isolates formed a clade distinct from other genera affiliated with the family Microbacteriaceae. The novel strains showed highest levels of $16 \mathrm{~S}$ rRNA gene sequence similarity with members of the genera Agreia and Subtercola (95.6-95.9\%). The level of 16S rRNA gene sequence similarity between strains AHU $1791^{\top}$ and AHU1810 was $99.8 \%$. The cell-wall peptidoglycan type of the two strains was B2 $\gamma$, containing 2,4-diaminobutyric acid as the diagnostic amino acid. The predominant menaquinones were MK-12 and MK-13 (strain AHU1791 ${ }^{\top}$ ) and MK-11 and MK-12 (strain AHU1810). The major fatty acids of the two strains were 12-methyl tetradecanoic acid (anteiso- $\mathrm{C}_{15: 0}$ ), 14-methyl hexadecanoic acid (anteiso- $\mathrm{C}_{17: 0}$ ), 14-methyl pentadecanoic acid (iso- $\mathrm{C}_{16: 0}$ ) and 13-methyl tetradecanoic acid (iso- $\mathrm{C}_{15: 0}$ ). The DNA G+C contents of strains AHU $1791^{\top}$ and AHU1810 were approximately $65 \mathrm{~mol} \%$. These phenotypic characteristics differentiated the ice-wedge strains from their closest phylogenetic neighbours, namely Subtercola boreus and the two recognized species of the genus Agreia. The sequences of the housekeeping genes coding for DNA gyrase subunit B $(g y r B)$, RNA polymerase subunit $\mathrm{B}(r p o B)$ and recombinase $\mathrm{A}(\operatorname{rec} A)$ were almost identical between strains $\mathrm{AHU} 1791^{\top}$ and $\mathrm{AHU} 1810$. Although the predominant menaquinones found in strains $\mathrm{AHU} 1791^{\top}$ and $\mathrm{AHU} 1810$ were different, no other distinct differences were found with regard to other phenotypic and genotypic characteristics, indicating that the two strains were members of the same species. Accordingly, strains $\mathrm{AHU} 1791^{\top}$ and $\mathrm{AHU} 1810$ are considered to represent a single novel species of a new genus, for which the name Glaciibacter superstes gen. nov., sp. nov. is proposed. The type strain of Glaciibacter superstes is AHU1791 ${ }^{\top}\left(=\mathrm{DSM} 21135^{\top}=\right.$ NBRC $\left.104264^{\top}\right)$.
\end{abstract}

The GenBank/EMBL/DDBJ accession numbers of the $16 \mathrm{~S}$ rRNA, gyrB, rpo $B$ and recA gene sequences of strains $A H U 1791^{\top}$ and $A H U 1810$ are $A B 378301$ and $A B 378302$ (16S rRNA), AB436916 and AB436917 (gyrB), AB436918 and AB436919 (rpoB) and AB436920 and AB436921 (recA), respectively.

Details of the primers used for determination of housekeeping genes and the effect of growth temperature on the cellular fatty acid composition of strain $\mathrm{AHU} 1791^{\top}$ are available as supplementary material with the online version of this paper.
At the time of writing, the family Microbacteriaceae comprises 25 genera that possess a B-type cross-linked peptidoglycan and fully unsaturated respiratory menaquinones. Psychrophilic bacteria within the family, for example members of the genera Cryobacterium (Suzuki et al., 1997; Zhang et al., 2007), Rhodoglobus (Sheridan et al., 2003) and Subtercola (Männistö et al., 2000), have been isolated from cold environments including soils and lakes in Antarctica, glacier ice and groundwater. Previously, we 
reported on the isolation of bacteria preserved within a permafrost ice wedge ice for 25000 years (Katayama et al., 2007). Phylogenetic analysis based on $16 \mathrm{~S}$ rRNA gene sequences indicated that two of the ice-wedge isolates, namely strains $\mathrm{AHU} 1791^{\mathrm{T}}$ and AHU1810, were distinct from genera within the family Microbacteriaceae. In the present paper, we describe strains $\mathrm{AHU} 1791^{\mathrm{T}}$ and AHU1810 further and suggest that they represent a novel species of a new genus in the family Microbacteriaceae.

Strains AHU $1791^{\mathrm{T}}$ and AHU1810 were isolated from an ice wedge in the Fox permafrost tunnel, Alaska, USA ( $64.952^{\circ}$ $\mathrm{N} 147.617^{\circ} \mathrm{W}$ ), which is preserved at about $-3{ }^{\circ} \mathrm{C}$ by the US Army's Cold Regions Research and Engineering Laboratory. Sample collection and isolation methods were as described by Katayama et al. (2007). Strains AHU1791 ${ }^{\mathrm{T}}$ and AHU1810 were originally isolated from agar plates containing Luria broth and minimal medium plus $0.5 \%$ glucose (Stanier et al., 1986), respectively. The strains showed good aerobic growth at $20{ }^{\circ} \mathrm{C}$ in trypticase soy broth (TSB) or R2A revised medium (R2AR), the latter consisting of $0.1 \%$ peptone, $0.1 \%$ Casamino acids, $0.1 \%$ $\mathrm{K}_{2} \mathrm{HPO}_{4}, 0.05 \%$ yeast extract and $0.03 \% \mathrm{MgSO}_{4} \cdot 7 \mathrm{H}_{2} \mathrm{O}$ $(\mathrm{pH} 7.2)$ supplemented with $1 \%$ D-glucose or $1 \%(\mathrm{v} / \mathrm{v})$ glycerol. Cell cultures used for all experiments were prepared in TSB at $20{ }^{\circ} \mathrm{C}$ unless indicated otherwise.

Chromosomal DNA was extracted and purified following the methods of Nakagawa et al. (2001). DNA G + C contents were determined by reversed-phase HPLC (Nakagawa et al., 2001). 16S rRNA gene sequences (Escherichia coli positions 28-1509) were determined and were aligned with their relatives by using ARB software (Ludwig et al., 2004) with reference to the SILVA database (Pruesse et al., 2007). The sequences of the housekeeping genes coding for DNA gyrase subunit B $(g y r B)$, RNA polymerase subunit B $(r p o B)$ and recombinase $\mathrm{A}(\mathrm{rec} A)$ were determined by using the primers described in Supplementary Table S1 (see IJSEM Online). Phylogenetic trees were constructed according to the neighbour-joining (Saitou \& Nei, 1987) and maximumlikelihood (Felsenstein, 1981) methods by using MEGA 4.0 (Tamura et al., 2007) and PAUP* (Swofford, 2003). An evolutionary distance matrix for the neighbour-joining method was generated according to Jukes \& Cantor (1969) by using complete deletion model analysis. Likelihood parameters were estimated via the hierarchical ratio tests implemented in MODELTEST 3.7 (Posada \& Crandall, 1998). The robustness of tree topologies was assessed by bootstrap analyses (Felsenstein, 1985) based on 1000 replications.

Cell morphology was observed under a light microscope (Olympus BX50), with cells grown in TSB at $15{ }^{\circ} \mathrm{C}$. Gram staining was performed as described by Hasegawa (1985). Colony pigmentation and morphology were observed for colonies grown on trypticase soy agar (TSA) at $15{ }^{\circ} \mathrm{C}$ for 10 days. Motility was determined based on the swarming test on R2AR agar $(0.25 \%$ agar $)$ at $15{ }^{\circ} \mathrm{C}$. Flagella were stained according to the method of Nishizawa and Sugawara (see Hasegawa, 1985). Cell growth under anaerobic conditions was examined on TSA supplemented with $1 \%$ D-glucose or $1 \%$ L-arabinose. Catalase and oxidase activities were determined by bubble formation in $3 \% \mathrm{H}_{2} \mathrm{O}_{2}$ solution and by use of an oxidase test kit (Wako), respectively. Acid production and assimilation of carbohydrates were determined by using API $50 \mathrm{CH}$ (bioMérieux) test strips. Growth at $-5,0,5,10,15,18,20,23$ and $25{ }^{\circ} \mathrm{C}$ on liquid R2AR supplemented with $1 \%$ glycerol was determined based on increases in optical density at $600 \mathrm{~nm}$. The upper temperature limit for growth was determined from colony formation on R2AR agar supplemented with $1 \%$ glycerol at 25,27 and $30{ }^{\circ} \mathrm{C}$.

Menaquinones were extracted as described by Collins et al. (1977) and were analysed by reversed-phase HPLC (Tamaoka et al., 1983). Cell walls were prepared by using the protocol of Komagata \& Suzuki (1987). Amino acids in acid hydrolysates of the cell walls were identified and quantified by TLC (Schleifer et al., 1967) and by using a JLC-500/S amino acid analyser (JEOL). Peptidoglycan acyl types were determined according to the method of Uchida et al. (1999). Fatty acid methyl esters were prepared as described by Suzuki \& Kudo (2001) and were analysed by using GC-MS (QP2010; Shimadzu).

The DNA $\mathrm{G}+\mathrm{C}$ contents of strains $\mathrm{AHU} 1791^{\mathrm{T}}$ and AHU1810 were 65.3 and $65.4 \mathrm{~mol} \%$, respectively. $16 \mathrm{~S}$ rRNA gene sequence analysis showed that strains AHU1791 ${ }^{\mathrm{T}}$ and AHU1810 were related most closely to the type strains of Agreia pratensis (95.9\% similarity), Agreia bicolorata (95.6\%), Subtercola boreus (95.7-95.8\%), Microterricola viridarii $(95.5 \%)$ and Okibacterium fritillariae (95.5\%). Lower levels of $16 \mathrm{~S}$ rRNA gene sequence similarity (91.6-94.7\%) were found with the type strains of all other type species within the family Microbacteriaceae. The neighbour-joining phylogenetic tree indicated that the icewedge strains formed a branch distinct from those of their related species (Fig. 1). This relationship was supported by a high level of bootstrap support. During alignments of the $16 \mathrm{~S}$ rRNA gene sequences, 12-bp insertions (E. coli position 457) were found in strains AHU1791 ${ }^{\mathrm{T}}$ and AHU1810. A 13-bp insertion in the same position was also observed in Rhodoglobus vestalii $\mathrm{LV}^{\mathrm{T}}$. The presence of this insertion was mentioned as a distinctive characteristic when strain $\mathrm{LV}^{\mathrm{T}}$ was proposed as a member of a new genus (Sheridan et al., 2003). The insertions were not observed in related taxa, such as A. pratensis, A. bicolorata and S. boreus. Phylogenetic relationships plus the presence of the insertions discussed above supported the designation of strains $\mathrm{AHU} 1791^{\mathrm{T}}$ and AHU1810 as representatives of a new genus. As shown in Fig. 1, S. boreus, the type species of the genus Subtercola, and Subtercola frigoramans were not closely related to each other. Thus, in the present study, the type strains of S. boreus, A. bicolorata and $A$. pratensis were used for further comparisons. The 16S rRNA gene sequence of strain AHU1791 ${ }^{\mathrm{T}}$ showed $99.8 \%$ similarity to that of strain AHU1810.

Those physiological and morphological characteristics common to the two novel strains are given in the genus 


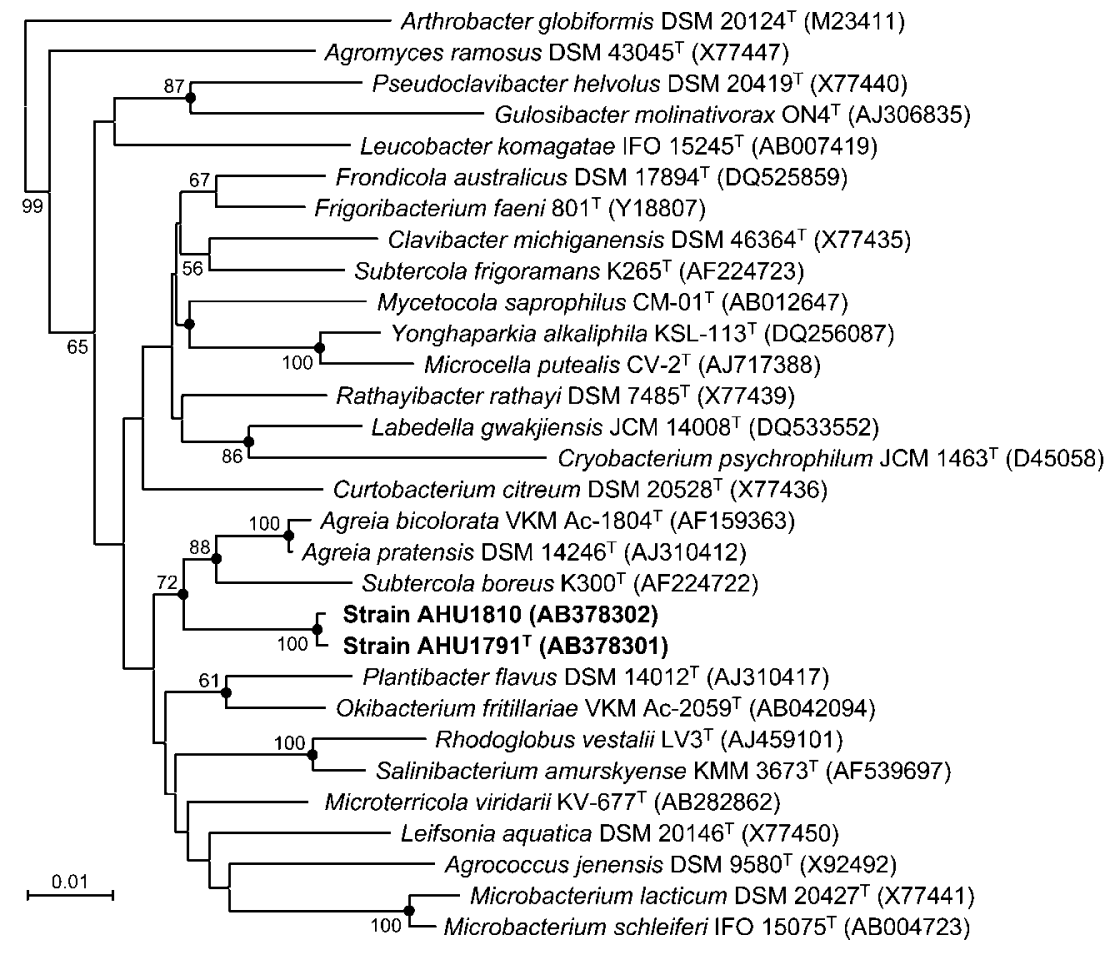

Fig. 1. Neighbour-joining tree showing the relationship between strains $\mathrm{AHU} 1791^{\top}$ and AHU1810 and the type strains of related taxa within the family Microbacteriaceae. Bootstrap values of $>50 \%$ are shown at nodes. Dots indicate branches that were also found in the maximum-likelihood tree. Brevibacterium linens DSM $20425^{\top}$ (GenBank accession no. $\mathrm{X} 77451)$ served as an outgroup (not shown). Bar, 0.01 substitutions per nucleotide position. and species descriptions below. Physiological differences found between strains AHU1791 ${ }^{\mathrm{T}}$ and AHU1810 were as follows. The maximum growth rate of strain AHU1791 ${ }^{\mathrm{T}}$ was observed at $20{ }^{\circ} \mathrm{C}$, whereas that of strain AHU1810 was observed at $18-20{ }^{\circ} \mathrm{C}$. Strain AHU1810 produced acid from D-arabinose whereas strain AHU1791 ${ }^{\mathrm{T}}$ did not.

The predominant menaquinones of strain $\mathrm{AHU} 1791^{\mathrm{T}}$ were MK-12 (50\% of the total quinones) and MK-13 (32\%), whereas those of strain AHU1810 were MK-11 (32\%) and MK-12 (45\%). Purified peptidoglycans of strains
AHU1791 ${ }^{\mathrm{T}}$ and AHU1810 contained 2,4-diaminobutyric acid, alanine, glycine and glutamic acid at a molar ratio of $2.0: 0.9: 1.3: 1.0$. Threo-3-hydroxyglutamic acid, found in the peptidoglycans of members of the genera Agreia and Subtercola in place of glutamic acid, was not detected in strains AHU1791 ${ }^{\mathrm{T}}$ or AHU1810. Schleifer \& Kandler (1972) reported that the hydroxylation of glutamic acid depends on oxygen supply during culturing. We confirmed the presence or absence of threo-3-hydroxyglutamic acid by culturing S. boreus DSM $13056^{\mathrm{T}}$, A. pratensis DSM $14246^{\mathrm{T}}$ and the ice-wedge strains under identical conditions.

Table 1. Differential characteristics between strains $\mathrm{AHU} 1791^{\top}$ and $\mathrm{AHU} 1810$ and S. boreus, A. pratensis and A. bicolorata

Data for reference species were taken from Männistö et al. (2000), Evtushenko et al. (2001) and Behrendt et al. (2002). DAB, 2,4-Diaminobutyric acid; Hyg, threo-3-hydroxyglutamic acid; Orn, ornithine; a, anteiso-branched fatty acids; i, iso-branched fatty acids; a- $\mathrm{C}_{15: 0}$ DMA, 1,1-dimethoxy anteiso-pentadecane; i-C 16 :0 DMA, 1,1-dimethoxy iso-hexadecane.

\begin{tabular}{|c|c|c|c|}
\hline Characteristic & Strains AHU1791 $/$ AHU1810 & S. boreus & A. bicolorata/A. pratensis \\
\hline Colony colour & White & Yellow & Yellow or orange/yellow \\
\hline Growth temperature range $\left({ }^{\circ} \mathrm{C}\right)$ & -5 to 25 & $2-28$ & $\leqslant 37 / \geqslant-2$ \\
\hline Optimum growth temperature $\left({ }^{\circ} \mathrm{C}\right)$ & $18-20$ & $15-17$ & $24-26$ \\
\hline Motility & + & - & $+1-$ \\
\hline Peptidoglycan amino acid(s) & $\mathrm{DAB}$ & DAB, Hyg & DAB, Orn, Hyg \\
\hline Predominant menaquinones (MK) & $12,13 / 11,12$ & 9,10 & $10 / 10,11$ \\
\hline Major fatty acids $(>5 \% \text { of the total })^{\star}$ & $a-C_{15: 0}, i-C_{16: 0}, a-C_{17: 0}, i-C_{15: 0}$ & $a-C_{15: 0}$ & $\mathrm{a}-\mathrm{C}_{15: 0}, \mathrm{i}-\mathrm{C}_{16: 0}, \mathrm{a}-\mathrm{C}_{17: 0} / \mathrm{C}_{16: 0^{\dagger}}$ \\
\hline Major 1,1-dimethoxy alkanes & None detected & $a-C_{15: 0}$ DMA, i-C $16: 0$ DMA & $\mathrm{a}-\mathrm{C}_{15: 0} \mathrm{DMA}$ \\
\hline DNA G + C content $(\mathrm{mol} \%)$ & 65 & 64 & $67 / 65$ \\
\hline
\end{tabular}

${ }^{\star}$ Fatty acid profiles are for cells cultured at the respective optimal growth temperature, i.e. 20 (ice-wedge strains), 15 (S. boreus) and 25 (Agreia species) ${ }^{\circ} \mathrm{C}$.

$\dagger$ Hexadecanoic acid $\left(\mathrm{C}_{16: 0}\right)$ comprised $>5 \%$ of the total fatty acids in A. pratensis. 
Muramic acid residues in the peptidoglycans of strains AHU $1791^{\mathrm{T}}$ and AHU1810 were acetylated, as were those of $S$. boreus DSM $13056^{\mathrm{T}}$. Fatty acids found in cells of strain AHU $17911^{\mathrm{T}}$ cultured at $20{ }^{\circ} \mathrm{C}$ were anteiso- $\mathrm{C}_{15: 0}(64.3 \%$ of the total), anteiso- $\mathrm{C}_{17: 0}(11.8 \%)$, iso- $\mathrm{C}_{16: 0}(11.0 \%)$, iso$\mathrm{C}_{15: 0}(7.5 \%)$ and anteiso- $\mathrm{C}_{15: 1}(4.4 \%)$. This profile was almost identical to that of strain AHU1810. The profile of major fatty acids distinguished the ice-wedge strains from $S$. boreus and the two recognized species of the genus Agreia (Table 1). In addition, 1,1-dimethoxy alkanes, the unique methanolysates observed in members of the genera Agreia, Subtercola and Frigoribacterium (Schumann et al., 2003; Kämpfer et al., 2000), were not detected in the ice-wedge strains. The proportion of anteiso- $\mathrm{C}_{15: 1}$ in strain $\mathrm{AHU} 1791^{\mathrm{T}}$ increased to $29 \%$ of the total fatty acids with a decrease in cultivation temperature to $-5{ }^{\circ} \mathrm{C}$, while the proportions of anteiso- $\mathrm{C}_{15: 0}$ and anteiso- $\mathrm{C}_{17: 0}$ decreased (see Supplementary Table S2). It is notable that, when strain AHU $1791^{\mathrm{T}}$ was cultured at $-5{ }^{\circ} \mathrm{C}$, the proportion of iso$\mathrm{C}_{15: 0}$ increased $(21 \%)$ and that of iso- $\mathrm{C}_{16: 0}$ decreased to a greater extent compared with that at $0{ }^{\circ} \mathrm{C}$, indicating that strain $\mathrm{AHU} 1791^{\mathrm{T}}$ altered its fatty acid composition by increasing the ratio of short-chain components as well as that of unsaturated components to maintain membrane fluidity at subzero temperatures.

Phenotypic characteristics indicated that the ice-wedge strains were clearly distinguished from their phylogenetic neighbours, S. boreus, A. bicolorata and A. pratensis (Table 1).

The lengths of the housekeeping gene sequences for strains AHU $1791^{\mathrm{T}}$ and AHU1810 were 1862 bp for gyrB [corresponding to gyrB positions 100-1973 of Leifsonia xyli subsp. xyli CTCB07 (GenBank accession no. NC_006087); 93.5\% of the total length], $2840 \mathrm{bp}$ for $r p o B$ [corresponding to rpoB positions $436-3276$ of $L$. xyli subsp. xyli CTCB07 (NC_006087); $81.2 \%$ of the total] and $819 \mathrm{bp}$ for recA [corresponding to recA positions 79-897 of L. xyli subsp. xyli CTCB07 (NC_006087); $72.8 \%$ of the total]. The gyrB, $r p o B$ and $r e c A$ gene sequences of strains $A H U 1791^{\mathrm{T}}$ and AHU1810 were almost identical, with $1 \mathrm{nt}$ difference in those of the $g y r B$ and $r p o B$ genes.

Levels of sequence similarity of the $g y r B, r p o B$ and $r e c A$ genes within the same region between Clavibacter michiganensis subsp. michiganensis NCPPB 382 (GenBank accession no. NC_009480) and C. michiganensis subsp. sepedonicus ATCC $33113^{\mathrm{T}}$ (NC_010407), which were compared as one of the criteria for subspecies discrimination, were 95.4, 98.5 and $95.0 \%$, respectively. By comparison, levels of sequence similarity for these three genes between the ice-wedge strains were much higher. Accordingly, although the predominant menaquinones were different between strains AHU1791 ${ }^{\mathrm{T}}$ and AHU1810, no further distinct differences were found with regard to other phenotypic and genotypic characteristics, suggesting that the two ice-wedge strains were affiliated with the same species.

Thus, strains AHU $1791^{\mathrm{T}}$ and AHU1810 are considered to represent a single novel species of a new genus, for which the name Glaciibacter superstes gen. nov., sp. nov. is proposed.

\section{Description of Glaciibacter gen. nov.}

Glaciibacter (Gla.ci.i.bac'ter. L. n. glacies ice; N.L. masc. n. bacter rod; N.L. masc. n. Glaciibacter a rod of the ice).

Cells are aerobic, Gram-positive, non-spore-forming, irregular rods. The cell-wall peptidoglycan is of $\mathrm{B} 2 \gamma$ type, containing 2,4-diaminobutyric acid as the diagnostic amino acid. The muramic acid is of acetyl type. The predominant menaquinones are MK-12 and MK-13 or MK-11 and MK-12. The major fatty acids are 12-methyl tetradecanoic acid (anteiso- $\mathrm{C}_{15: 0}$ ), 14-methyl hexadecanoic acid (anteiso- $\mathrm{C}_{17: 0}$ ), 14-methyl pentadecanoic acid (iso- $\mathrm{C}_{16: 0}$ ) and 13-methyl tetradecanoic acid (iso- $\mathrm{C}_{15: 0}$ ). The $\mathrm{G}+\mathrm{C}$ content of the DNA is about $65 \mathrm{~mol} \%$. The type species is Glaciibacter superstes.

\section{Description of Glaciibacter superstes sp. nov.}

Glaciibacter superstes (su.per'stes. L. masc. adj. superstes surviving).

Has the following characteristics in addition to those given for the genus. Cells are 1.1-1.8 $\times 0.3-0.5 \mu \mathrm{m}$ in size, motile by means of a single polar flagellum. Mycelium formation does not occur. V-shaped forms are found at the early stages of growth in liquid culture. Cells exhibit a rod/ coccus life cycle in TSB. Colonies are round, smooth, slightly shiny, convex and white on TSA. Cell aggregations are observed when cells are grown at above $15{ }^{\circ} \mathrm{C}$ in TSB. Growth occurs at -5 to $25{ }^{\circ} \mathrm{C}$. The optimal temperature for growth is approximately $20{ }^{\circ} \mathrm{C}$. Catalase-positive and oxidase-negative. Acid is produced from L-arabinose, Dfructose, D-galactose, D-glucose, D-mannose, L-rhamnose, D-xylose, D-ribose, cellobiose, maltose, sucrose, turanose, D-mannitol, xylitol and glycerol, but not from DL-fucose, Lxylose, trehalose, raffinose, D-sorbitol, starch or inulin. Acid production from D-arabinose is strain-dependent. The $\mathrm{G}+\mathrm{C}$ content of the DNA is $65.3-65.4 \mathrm{~mol} \%$. The $16 \mathrm{~S}$ rRNA gene sequence contains a 12-nt insertion (E. coli position 457).

The type strain, AHU1791 ${ }^{\mathrm{T}}$ (=DSM $21135^{\mathrm{T}}=\mathrm{NBRC}$ $104264^{\mathrm{T}}$ ), was isolated from an ice wedge in the Fox permafrost tunnel, Alaska, USA. Strain AHU1810, isolated from the same source, is a second strain of the species.

\section{Acknowledgements}

This study was supported in part by a grant from the Institute for Fermentation, Osaka.

\section{References}

Behrendt, U., Ulrich, A., Schumann, P., Naumann, D. \& Suzuki, K. (2002). Diversity of grass-associated Microbacteriaceae isolated from the phyllosphere and litter layer after mulching the sward; polyphasic 
characterization of Subtercola pratensis sp. nov., Curtobacterium herbarum sp. nov. and Plantibacter flavus gen. nov., sp. nov. Int J Syst Evol Microbiol 52, 1441-1454.

Collins, M. D., Pirouz, T., Goodfellow, M. \& Minnikin, D. E. (1977). Distribution of menaquinones in actinomycetes and corynebacteria. J Gen Microbiol 100, 221-230.

Evtushenko, L. I., Dorofeeva, L. V., Dobrovolskaya, T. G., Streshinskaya, G. M., Subbotin, S. A. \& Tiedje, J. M. (2001). Agreia bicolorata gen. nov., sp. nov., to accommodate actinobacteria isolated from narrow reed grass infected by the nematode Heteroanguina graminophila. Int J Syst Evol Microbiol 51, 2073-2079.

Felsenstein, J. (1981). Evolutionary trees from DNA sequences: a maximum likelihood approach. J Mol Evol 17, 368-376.

Felsenstein, J. (1985). Confidence limits on phylogenies: an approach using the bootstrap. Evolution 39, 783-791.

Hasegawa, T. (1985). In Classification and Identification of Microorganisms, pp. 109-118. Tokyo: Japan Scientific Societies Press (in Japanese).

Jukes, T. H. \& Cantor, C. R. (1969). Evolution of protein molecules. In Mammalian Protein Metabolism, vol. 3, pp. 21-132. Edited by H. N. Munro. New York: Academic Press.

Kämpfer, P., Rainey, F. A., Andersson, M. A., Lassila, E.-L. N., Ulrych, U., Busse, H.-J., Mikkola, R. \& Salkinoja-Salonen, M. (2000). Frigoribacterium faeni gen. nov., sp. nov., a novel psychrophilic genus of the family Microbacteriaceae. Int J Syst Evol Microbiol 50, 355-363.

Katayama, T., Tanaka, M., Moriizumi, J., Nakamura, T., Brouchkov, A., Douglas, T. A., Fukuda, M., Tomita, F. \& Asano, K. (2007). Phylogenetic analysis of bacteria preserved in a permafrost ice wedge for 25,000 years. Appl Environ Microbiol 73, 2360-2363.

Komagata, K. \& Suzuki, K. (1987). Lipid and cell wall analysis in bacterial systematics. Methods Microbiol 19, 161-207.

Ludwig, W., Strunk, O., Westram, R., Richter, L., Meier, H., Yadhukumar, Buchner, A., Lai, T., Steppi, S. \& other authors (2004). ARB: a software environment for sequence data. Nucleic Acids Res 32, 1363-1371.

Männistö, M. K., Schumann, P., Rainey, F. A., Kämpfer, P., Tsitko, I., Tiirola, M. A. \& Salkinoja-Salonen, M. S. (2000). Subtercola boreus gen. nov., sp. nov. and Subtercola frigoramans sp. nov., two new psychrophilic actinobacteria isolated from boreal groundwater. Int $J$ Syst Evol Microbiol 50, 1731-1739.

Nakagawa, K., Tamura, T. \& Kawasaki, H. (2001). In Identification Manual of Actinomycetes, pp. 83-133. Edited by The Society for Actinomycetes Japan. Tokyo: Business Center for Academic Societies Japan (in Japanese).

Posada, D. \& Crandall, K. A. (1998). MODELTEST: testing the model of DNA substitution. Bioinformatics 14, 817-818.
Pruesse, E., Quast, C., Knittel, K., Fuchs, B. M., Ludwig, W., Peplies, J. \& Glockner, F. O. (2007). SILVA: a comprehensive online resource for quality checked and aligned ribosomal RNA sequence data compatible with ARB. Nucleic Acids Res 35, 7188-7196.

Saitou, N. \& Nei, M. (1987). The neighbor-joining method: a new method for reconstructing phylogenetic trees. Mol Biol Evol 4, 406-425.

Schleifer, K. H. \& Kandler, O. (1972). Peptidoglycan types of bacterial cell walls and their taxonomic implications. Bacteriol Rev 36, 407-477.

Schleifer, K. H., Plapp, R. \& Kandler, O. (1967). Identification of threo-3-hydroxyglutamic acid in the cell wall of Microbacterium lacticum. Biochem Biophys Res Commun 28, 566-570.

Schumann, P., Behrendt, U., Ulrich, A. \& Suzuki, K. (2003). Reclassification of Subtercola pratensis Behrendt et al. 2002 as Agreia pratensis comb. nov. Int J Syst Evol Microbiol 53, 2041-2044.

Sheridan, P. P., Loveland-Curtze, J., Miteva, V. I. \& Brenchley, J. E. (2003). Rhodoglobus vestalii gen. nov., sp. nov., a novel psychrophilic organism isolated from an Antarctic Dry Valley lake. Int J Syst Evol Microbiol 53, 985-994.

Stanier, R. Y., Ingraham, J. L., Wheelis, M. L. \& Painter, P. R. (1986). The methods of microbiology. In The Microbial World, 5th edn, p. 28. Englewood Cliffs, NJ: Prentice Hall.

Suzuki, K. \& Kudo, T. (2001). In Identification Manual of Actinomycetes, pp. 72-76. Edited by The Society for Actinomycetes Japan. Tokyo: Business Center for Academic Societies Japan (in Japanese).

Suzuki, K., Sasaki, J., Uramoto, M., Nakase, T. \& Komagata, K. (1997). Cryobacterium psychrophilum gen. nov., sp. nov., nom. rev., comb. nov., an obligately psychrophilic actinomycete to accommodate "Curtobacterium psychrophilum" Inoue and Komagata 1976. Int J Syst Bacteriol 47, 474-478.

Swofford, D. L. (2002). PAUP* ${ }^{*}$ Phylogenetic analysis using parsimony (and other methods), version 4. Sunderland, MA: Sinauer Associates.

Tamaoka, J., Katayama-Fujimura, Y. \& Kuraishi, H. (1983). Analysis of bacterial menaquinone mixtures by high performance liquid chromatography. J Appl Bacteriol 54, 31-36.

Tamura, K., Dudley, J., Nei, M. \& Kumar, S. (2007). MEGA 4: molecular evolutionary genetics analysis (MEGA) software version 4.0. Mol Biol Evol 24, 1596-1599.

Uchida, K., Kudo, T., Suzuki, K. \& Nakase, T. (1999). A new rapid method of glycolate test by diethyl ether extraction, which is applicable to a small amount of bacterial cells of less than one milligram. J Gen Appl Microbiol 45, 49-56.

Zhang, D.-C., Wang, H.-X., Cui, H.-C., Yang, Y., Liu, H.-C., Dong, X.-Z. \& Zhou, P.-J. (2007). Cryobacterium psychrotolerans sp. nov., a novel psychrotolerant bacterium isolated from the China No. 1 glacier. Int $J$ Syst Evol Microbiol 57, 866-869. 